\title{
THE DEVELOPMENT OF EPSAS: CONTRIBUTIONS FROM THE LITERATURE
}

\begin{abstract}
EPSAS are being considered in the EU context where a need for harmonisation in Governmental Accounting (GA) has been recognised as important to increase the reliability of sources of information to the National Accounts (NA) figures. However, GA and NA are two different and parallel reporting systems at national level, even if, within the European context, EPSAS intend to contribute for their convergence.

The relationship between GA and NA has been recurrently addressed in the literature over the last two decades, with professionals being more proactive while academics have been more reactive in the debate. Several issues have been raised. This paper recaptures and revises these issues, synthesising academic and practitioner literature, archival documents and reports of EU working groups, from 1996 to 2018.

The analysis highlights the more controversial areas, and those that seemed already settled but yet are now, within the context of EPSAS development, being raised again. Specifically, the paper calls attention to (1) the need to manage between two different conceptual frameworks of GA and NA; (2) the importance of interdisciplinary collaboration between the professionals involved, namely accountants, public administrators and statisticians; (3) the role of budgetary accounting and the alignment required between reporting in GA and NA, reducing and harmonising adjustments to be made when translating data from one into the other; and (4) the need to address auditing issues, as EPSAS on their own may not be enough to ensure reliability of the information reported.
\end{abstract}

Keywords: governmental accounts; national accounts; convergence; accountability; macro-economic surveillance.

\section{List of abbreviations:}

EPSAS

ESA

EU

GA
European Public Sector Accounting Standards

European System of National and Regional Accounts

European Union

Governmental Accounting 


$\begin{array}{ll}\text { GFS } & \text { Government Finance Statistics } \\ \text { GGS } & \text { General Government Sector } \\ \text { IASB } & \text { International Accounting Standards Board } \\ \text { IFAC } & \text { International Federation of Accountants } \\ \text { IFRS } & \text { International Financial Reporting Standards } \\ \text { IPSAS } & \text { International Public Sector Accounting Standards } \\ \text { IPSASB } & \text { International Public Sector Accounting Standards Board } \\ \text { NA } & \text { National Accounts } \\ \text { OECD } & \text { Organization for Economic Co-operation and Development } \\ \text { SNA } & \text { System of National Accounts }\end{array}$

\section{Introduction}

Events in the mid-90s drew the attention of professionals, standard-setters and other international institutions to the relationship between Governmental Accounting (GA) and National Accounting (NA). A new system of NA issued by the United Nations (SNA93) was adapted to the European context in 1995 (ESA95). The SNA93, and therefore ESA95, were more strongly rooted in the accrual-based approach. At the same time, in Europe, the Maastricht Treaty was signed, as a prelude to the European Monetary Union, setting fiscal convergence criteria based on NA figures, which themselves needed to be based on GA data mainly extracted from budgetary reporting. In particular, the framework of the Excessive Deficit Procedure was established in 1993. In 1996, the foundation of the International Federation of Accountants (IFAC)'s Public Sector Committee brought to the fore international harmonisation issues in public sector 
accounting and the relevance of the accrual-based approach also for GA. GA includes financial reporting and budgetary reporting.

Since then, GA and NA have featured in academic research and non-academic debate. Studies and papers issued by international organisations, such as the International Monetary Fund, the World Bank and the IFAC, have been complemented with academic literature. Following the European Union (EU)'s interest in GA, there are also various studies and working papers by EU working groups and professional bodies ${ }^{1}$.

The link between GA and NA is more obvious as data from GA (particularly, budgetary reporting) is used as input for NA. Thus, the quality of GA data could affect the reliability of NA reports that, in the EU context, are required to satisfy important agreements between Member States, and also to enable EU macroeconomic surveillance, especially within the Euro Area (Benito et al., 2007; Jones and Lüder, 1996; Lüder, 2000; Martí, 2006; Montesinos and Vela, 2000). Consequently, in the EU, a need for GA harmonisation has been recognised as important to increase the reliability of sources of information for NA figures, leading to the conceptualisation of the European Public Sector Accounting Standards (EPSAS) project in 2013. It appears that the EPSAS are intended to address GA rather than NA, but also to contribute to a possible convergence of these two reporting systems, with key NA standard setters, like the Eurostat, involved in the EPSAS development process. Such a convergence has been discussed in the literature for over 20 years - even before EPSAS were conceived - and several issues were raised, which can be classified under four categories as follows:

(i) The consequences of the fundamental differences in the underlying conceptual frameworks

\footnotetext{
${ }^{1}$ The table in the Appendix displays the main professional reports and documents prepared from 1996 to April 2018, showing the increasing awareness of several organisations of the importance to address GANA relationship topics.
} 
Given the fact that GA and NA are two separate reporting frameworks (Lalibertè, 2004; Vanoli, 2005), having different objectives that cater for the needs of different users (Keuning and Tongeren, 2004; Khan and Mayes, 2009; Van der Hoek, 2005), some studies have examined in detail how and why the underlying conceptual frameworks lead to different reporting boundaries and measurement criteria relating to assets and liabilities and surplus or deficit (Dabbicco, 2018; IPSASB, 2005, 2012b).

(ii) The institutional development and the underlying professions

Some studies have analysed the historical development of these two reporting frameworks, and how they overlapped over time (Jones, 2000a, 2000b; Jones and Lüder, 1996). This overlap has been studied both technically and institutionally, with the latter referring to the roles of the different professionals involved in the processes of GA and NA, each with different points of view - liaising and sometimes conflicting (Guthrie, 1998; Heald and Hodges, 2015).

(iii) The link between GA and NA and possible convergence Various studies have examined how GA data is used for NA purposes, and whether using different bases of preparation of GA, can affect NA and how (Dabbicco, 2013; 2015a; Jesus and Jorge, 2014, 2015; Dabbicco and D’Amore, 2016). Technical overlap instigated further studies about whether or not, or to what extent, these two frameworks can converge; and what would be the objective of such convergence (Heiling et al., 2013; IMF et al., 2006; Jesus and Jorge, 2014; Lequiller, 2015; Jorge et al., 2016a; Dasí et al, 2016; Sforza and Cimini, 2017).

(iv) The role of budgetary accounting and auditing

Given the important role of budgeting for governmental financial management, budgetary accounting has been studied through the lenses of the two conceptual 
frameworks of GA and NA (Jones, 2000b). It has been suggested that budgetary accounting could actually act as the bridge between these two types of reporting frameworks (Jones, 2014). Finally, the role of auditing, though to a lesser extent, has also been addressed (Jones, 2000b, 2014; Jones and Caruana, 2015; Caruana and Grima, 2019).

In the current debate, it seems that some matters previously settled are being neglected. The objective of this paper is to revisit the literature and recapture and synthesise what has already been researched and discussed. By condensing prior literature in this way, attention is drawn to what has already been concluded. This study can then contribute to the literature by acting as a springboard for future discussion, which is fruitful and not repetitive. More importantly, the synthesis of 20+ years of research may assist the EPSAS project to develop on a sounder foundation. The contribution to practice is that the conclusion of this study proposes relevant indicators that can be considered for the way forward in the development of the EPSAS project.

The reflections presented in this paper, based on past literature, are of interest to both academics and practitioners, as the paper highlights the main issues to be managed by standard-setters in their conceptual frameworks, both at accounting (micro financial and budgetary reporting) and statistical levels, whilst avoiding any unnecessary divergences between the two systems. Since EPSAS are in their formative phase as a project, International Public Sector Accounting Standards (IPSAS) are generally taken as the 'benchmark' for GA standards, with the understanding that EPSAS will likely be based on IPSAS (EC, 2013b). 
The paper proceeds by describing the research methodology in Section 2. The findings from the meta-analysis of the literature are presented in Section 3, which are then analysed and discussed in Section 4. Section 5 concludes with a summary of the most important issues and their implications for the development of EPSAS.

\section{Research methodology}

A qualitative research methodology is applied using documentary research (Ahmed, 2010). According to Prior (2003), the production and consumption of a document must be critically and contextually understood. Documentary analysis entails the consideration of who produced the document and for what purpose; the circumstances in which the document was produced, that is, the events and influences surrounding its production; the target audience; how the document was distributed, read and subsequently referred to; and what interests underlay the document (McCulloch and Richardson, 2000).

As previously stated, the objective of the paper is achieved through a metaanalysis of academic and practitioner literature, archival documents and reports of EU working groups, over the period 1996 to April 2018, regarding matters related to GA and NA, especially within the European setting. The literature used in this meta-analysis may not be exhaustive. Academic papers on GA and NA proved difficult to identify from library data bases because the topics are not always clearly identified in the titles, and the keywords used can sometimes be misleading. For example, 'national accounting' or 'national accounts' are sometimes used to refer to national accounting standards (at micro level) rather than statistical governmental reporting. Table 1 presents a summary of the main journals considered. 
The identification of relevant books and book chapters was easier: nine books and six book chapters were included in the analysis.

Relevant papers issued by professional bodies, international organisations and EU working groups also proved easier to identify because the titles are more clearly related to the contents. Table 2 lists the non-academic documents used in the analysis.

\section{[Insert Table 2 here]}

All these documents have been analysed with an approach best characterised as qualitative conventional content analysis (Hsieh and Shannon, 2005), from which topics related to GA and NA issues have emerged. These topics were categorised into four areas, namely (i) the conceptual frameworks - users and objectives of GA and NA; (ii) the institutional development and the underlying professions; (iii) the link between GA and NA and possible convergence; and (iv) the role of budgetary accounting and auditing. The findings in Section 3 are thus presented in these four sub-sections; and in section 4, the findings under each category are analysed accordingly.

\section{Findings}

\subsection{The conceptual frameworks}

The literature has delved into considerable detail regarding the conceptual frameworks of both GA and NA, highlighting differences and similarities of these two reporting systems. The starting point of any reporting 'Conceptual Framework' is a reflection on the needs of information of its users, because the objectives of reporting should then cater for these needs. The following summary of the literature first focuses on the conceptual framework 
of GA, and then compares it with that of NA, highlighting the implications of the fundamental differences.

According to Chan (2003), users of GA information may use it either for decision making (information function) or to account for public spending (accountability function). The information function focuses on service recipients (i.e. citizens) and resource providers (i.e. taxpayers, donor agencies, creditors). The concept of citizens can be broadened to the legislature, their representatives and other members of the public, who are also deemed as primary users of GA information (as representatives of the interests of service recipients and resource providers). With regards to the accountability function, governments and other public sector entities are responsible for the use of the resources at their disposal, and must therefore be accountable to both resource providers and service recipients. The accountability function covers more broadly the way in which GA serves different purposes (including safeguarding public funds and facilitating sound financial management - see Chan, 2003:14). It also deals with ex-ante accountability (authorisation of activities) and ex-post or concomitant accountability (for the results and outcome of activities). Therefore, the accountability function in GA involves budgetary reporting too, i.e., reporting on the compliance with approved budgets.

The accountability dimension in a GA context is dependent on the institutional environment, such as standard setting authorities and a set of standards (Chan, 2003), which calls for an underlying framework and suitable accounting concepts, standards and processes (Barton, 2011). This may be seen in the development of a conceptual framework, which should provide standard-setters and preparers with a reference for developing standards and guidelines.

The International Public Sector Accounting Standard Board (IPSASB) plays a key international role in the development of high quality accounting standards and practices. 
The IPSAS are the sole internationally recognised accrual-based public sector reporting standards to date (EC, 2013b).

IPSAS essentially relate to financial statements. They are not legally binding, but are considered to be authoritative when a jurisdiction decides to adopt them. 'Financial statements present information about the resources of the reporting entity or group reporting entity and claims to those resources at the reporting date, and changes to those resources and claims and cash flows during the reporting period' (IPSASB, 2014b, para. 4.6). The reporting entity, in any case, has a microeconomic and organisational scope, even if a whole-of-government perspective is considered.

Recommended Practice Guidelines have also been prepared by the IPSASB to provide guidance on good practice in preparing General Purpose Financial Reports other than financial statements. In fact, the IPSAS conceptual framework draws a boundary of financial reporting that is considerably broader than financial statements, namely including information about 'compliance with approved budgets and other authority governing [entities'] operations' (IPSASB, 2014b, para. 2.17). General Purpose Financial Reports are defined by the IPSAS conceptual framework as 'financial reports intended to meet the information needs of users who are unable to require the preparation of financial reports tailored to meet their specific information needs' (IPSASB, 2014b, para. $1.4)$.

The IPSASB analysed the key characteristics of the public sector in developing its conceptual framework. Accordingly, the IPSAS conceptual framework acknowledges the importance of reporting about the accomplishment of approved budgets (also reflected in IPSAS 24), and identifies the primary purpose of financial reporting as providing useful information for both resource providers and service recipients. IPSAS financial statements are thus focused on providing information for decision making, and allow for 
the entity's accountability about the resources made available to it (Dabbicco, 2015b, 2018; IPSASB, 2014b).

The IPSAS conceptual framework also covers several other aspects - the qualitative characteristics of the information to be provided, the notion of the reporting entity, the definition of the elements and recognition criteria in financial statements, measurement of assets and liabilities, and the presentation of information (IPSASB, 2014b; 2014c).

In contrast to GA, the NA's overall objective is to faithfully represent the complete economy for economic analyses and to meet the needs of decision-makers and politicians, for policy making (Bos, 2007; Lequiller and Blades, 2006, 2014).

The 2008 System of National Accounts (SNA) (United Nations, European Commission, IMF, Organisation for Economic Co-Operation and Development [OECD], World Bank, 2009) is a worldwide framework for statistical accounts, providing a systematic and detailed description of a total economy (of a region, a country or group of countries), its components (including interaction between economic sectors) and its relations with other economies. The 2010 European System of Regional and National Accounts (ESA) (EC, 2013c), is consistent with the 2008 SNA but it was elaborated considering specific EU needs, for example, that the ESA is a European legal regulation, which must be followed by all EU Member States.

National Accounts provide complete and comparable quantitative descriptions of economies, with an integrated system of accounts (transactions and balance sheets). The accounts cover both the whole economy and groups of entities within it (institutional sectors). NA data can be used for both structural and cyclical analyses, being 'optimal for economic analysis and the evaluation of economic policy' (ESA 2010 para. 1.25 (d), 1.26, EC, 2013c). 
The multi-purpose NA framework provides a systematic description of the economic process (production, generation of income, distribution of income, redistribution of income, use of income and financial and non-financial accumulation). The system includes balance sheets, which focus on the stock of assets, liabilities and net worth at the end of an accounting period, for each institutional sector or for an economy as a whole. NA also provides a means to analyse production processes, in a macroeconomic perspective, in substantial detail (Bos, 2007; Lequiller and Blades, 2006, 2014; Vanoli, 2005).

NA works on a building-block approach, where individual entity accounts (at the micro level) are aggregated to the macroeconomic level (Onida, 2004).

The General Government Sector is one NA sector. It contains so-called 'institutional units', which are non-market producers financed by compulsory payments made by units belonging to other sectors, and also institutional units principally engaged in the redistribution of national income and wealth (Dabbicco, 2015b). General Government National Accounts are a complete elaboration of data relating to the General Government Sector and its subsectors, in the common presentation of the central framework (ESA), as for any other part of economy. The Government Finance Statistics (GFS) presentation is an alternative way to represent the ESA data, with specific measures of government activity, such as revenue and expenditure, deficit/surplus, financing, assets and liabilities and other flows. Both presentations, contain stock positions and economic flows, and these are covered in multiple statements.

EU macroeconomic policymaking relies very heavily on NA statistics. One reason may be because ESA is an international harmonised reporting system while GA is not (yet). The European Commission has to ensure a legal requirement for EU Member States to transmit data to Eurostat. These tables of accounts are included in the ESA2010 
transmission programme. The Excessive Deficit Procedure and the Stability and Growth Pact are also based on NA data, as presented in the GFS alternative approach.

Although statistical reporting has learned from the principles of business accounting (Monducci et al., 2003), there are some fundamental differences in approach with business accounting, given that NA takes an economic theory perspective, which may be seen through the basic concepts of production, consumption and capital formation (Verrinder, 2008). Consequently, conceptual and presentational differences are observable between GA and NA/GFS, since they are intended to meet different user needs, and can therefore take different approaches to the same issue (Barton, 2009; 2011).

\section{[Insert Table 3 here]}

Table 3 shows a comparison of the two reporting frameworks in relation to the various issues raised in the literature. There are clearly two different perspectives of reporting: the one of NA - macro perspective supported on economics concepts; and the one of GA - micro perspective based on accounting and reporting principles. For example, the GFS perspective generally requires the use of current market value, whilst GA financial statements are often prepared in practice on a mainly historic cost measurement basis, using market value only where it is allowed (Jones, 2003; Dabbicco, 2018; IMF, 2006; IPSASB, 2005, 2012a).

It can also be noted that the definition of the reporting entity and the process of aggregation (the so-called 'reporting boundary') differ between GA and NA (Heald and Georgiou, 2009, 2011). Whereas the reporting entity is rather flexibly defined in GA and in IPSAS (potentially ranging from a single entity to the whole public sector), the ESA refers to institutional units aggregated into the General Government Sector (Dabbicco, 2015b). 
There are also some differences in the way recognition criteria operate. Whilst both systems are based on an accruals approach, NA has some exceptions and may be implemented in a different way in GA (Dabbicco, 2018; Jesus and Jorge, 2010). Moreover, GA reports, embracing financial and budgetary accomplishment statements, might include a mixture of recognition basis, inasmuch as budgetary rules vary across countries.

Despite the diversity of budgets and budgetary accounting regulations across countries, budgetary reporting is, as underlined, included in broader General Purpose Financial Reports, therefore making part of (micro) GA. In most EU countries, given the non-existence of whole of government financial accounts, consolidated budgetary reporting is the starting point for the adjustments to be made to the final figures in NA regarding the General Government Sector.

\section{Institutional development and the underlying professions}

The institutional relationship between GA and NA is described in the literature, together with the professions involved in both. It is deemed important to clarify at the outset that, while NA has always been highly standardised, the same cannot be said about GA. In fact, the GA landscape has been described as consisting of a plethora of different regulations and practices, with jurisdictions preferring to exercise their sovereign right to report according to national exigencies. However, over time, and even more in recent years, there has been an international trend for the harmonisation of GA. This trend has led GA to embrace more accrual accounting practices. While some jurisdictions developed accrual accounting principles and practices bespoke for their public sector peculiarities, it is observed that others, mostly jurisdictions with Anglo Saxon origin and links, are influenced by private sector accrual accounting practices. Thus, when some 
literature refers to accrual accounting at micro level, business accounting and financial reporting, it would be referring to GA.

The development and first official publication of NA took place in the 1930s and 1940s, originally in the United States and in the United Kingdom, based on the work of Simon Kuznets (Nobel Prize 1971) and Richard Stone (Nobel Prize 1984). They drew extensively, in conceptual terms, from the macroeconomic theory being developed at the time (Keynes, 1937, cited by Tily, 2009; Hicks, 1939, cited by Jones, 2014). Governments required macroeconomic data for policy uses, for example, for monitoring the impact of the US government's New Deal policies and the European reconstruction under the Marshall Plan. The latter gave an incentive to develop an international system of accounting, as comparable data were required across countries (Bos, 1995; 2008; Dabbicco, 2016; Jones, 2000b; Lequiller and Blades, 2006, 2014; Verrinder, 2008).

Recognising the need for international comparability (and also, more narrowly, the need to determine a country's contribution), the League of Nations (later, United Nations) published the first set of NA standards in 1947. Subsequently, more elaborated versions of these standards have been published through a collaboration between the United Nations, the IMF, the World Bank, the OECD and the European Commission (Bos, 1996, 2007, 2008; Jones, 2000b; Lequiller and Blades, 2006, 2014; Tily, 2009, 2010; Vanoli, 2005). The development of NA has involved collaboration between official statisticians, academics, macroeconomists and business accounting specialists. In this way, the National Accounts are based on economic concepts, but are presented in a business accounting-type framework.

Jones (2000b) refers to the institutionalisation of the distinction between GA and NA in The Economist in 1941, which stated that the bookkeeping aspect of a government's budget was the product of the Treasury, while national income statistics 
were the product of the national statistics institutions. He also recounts how an attempt by an accountant to understand the developments in NA, only managed to confirm the entrenched differences. The accountant found NA too complex, stating that the accountant's financial statements would solve these problems since '[A]ccounting is essential to all economic thinking conducted from a factual basis, because it gives a factual record in an orderly manner' (Bray, 1955, cited in Jones, 2000b:108). At the same time, economists criticised accounting systems for their limitations as they should be drawn up with a proper knowledge of the many complicated transactions that actually take place in an economy' (Stone, 1947, cited in Jones, 2000b:107).

Jones (2014:72) refers to a period when the accountancy profession 'dabbled' with NA and the resulting controversial inflation accounting in the 1960s and 1970s. According to Jones (2014), this interlude only confirmed that accountants are more concerned with business accounting, and remain rather ignorant about NA. Various attempts have been made to compare business accounting, GA (based on IPSAS), and NA (e.g. IPSASB, 2005, 2012a, 2012b, 2013, 2014a; United Nations, 2000), but the results were not clear because of the underlying difference in their objectives (as highlighted in section 3.1). Although statisticians and accountants have benefited from their on-going mutual dialogue, this perception of lack of clarity persists and suggests that the dialogue should continue.

The growing discourse on New Public Management and the adoption of private sector practices in the public sector, laid the ground for the accountancy profession to penetrate public administration; and this coincided with the period when the accountancy profession, through the IFAC, was establishing itself as a strong institution on an international scale. 
The IPSAS, as already referred, are issued by the IFAC through the independent IPSASB; whereas the International Financial Reporting Standards (IFRS) are set by the International Accounting Standards Board (IASB). Rocher (2010) reveals the coincidental sequence of events that resulted in the IPSAS not falling under the realm of the IASB as well, because that was the original intention. Still, the IFAC and the IASB can be regarded as 'brothers in arms' in their cooperation when developing private and public sector accounting standards besides in other areas, like auditing. The development of IPSAS is primarily drawn from IFRS - their private sector equivalent - a clear example of the influence exerted by private sector practices on the public sector. The strategic plan of the IPSASB confirms the convergence strategy of IPSAS with IFRS (IPSASB, 2018).

Neither the IPSASB nor the accountancy profession can enforce compliance with IPSAS. But according to Djelic and Quack (2008), Anglo-Saxon players, like the IFAC, benefit from something akin to a 'trademark' advantage in professional fields, which allows them to be forceful and convincing in the promotion of their own sets of rules. The IPSAS gained in importance as internationally accepted standards due to the support being given to them by international and supranational organisations ${ }^{2}$ (Jorge et al., 2019). The Asian Development Bank, the IMF and the World Bank relate financial aid given to developing countries with the implementation of procedures and structures based on IPSAS. The IPSAS were further legitimised when international organisations, like the OECD, the North Atlantic Treaty Organization and the United Nations, adopted them for their own financial reporting (Ball, 2011). The EU institutions followed in 2005, and adopted IPSAS for their own reporting, even though with some adaptations (Grossi and

\footnotetext{
${ }^{2}$ The same thing had happened with IFRS in 1995, with the recognition awarded by the International Organisation of Securities Commissions and the EU.
} 
Soverchia, 2011). Together with other international bodies, the EU (Budget's Directorate and Eurostat) has a presence on the IPSASB, albeit as observers; while the Chair of the IPSASB is a member of the EU's Advisory Group on Accounting Standards.

Due to the established long-standing relationship between the European Commission and the IPSASB, it is only natural that when faced with the financial crisis, the European Commission turned on the accountancy profession for a solution. In its comments on the proposed budgetary directive to improve fiscal discipline, the European Parliament (2011) had suggested the adoption of IPSAS by Member States within three years of the new directive coming into force. But in its final version of this directive, the European Commission (EU, 2011) took a softer approach and first considered the suitability of IPSAS for adoption by the Member States by carrying out a study by the end of 2012. While the requirement to change GA to an accrual basis seemed as the acceptable next step, the dispute arose as to whether the IPSAS are suitable or required at all (EC, 2013b).

For a reform in public sector accounting to be successful, the two types of expertise offered by the two 'professions' - accountants and public service officials- are required (Chan, 2003; Jackson and Lapsley, 2003). Collaboration can then only present a win-win situation. The adoption of accrual accounting methodologies and the attendant IPSAS or IPSAS-like standards, would attract accountants from the private sector to the public sector, and they would be in a better position to offer their professional advice and services; while public service officials would gain in reputation and not merely perceived as bureaucrats (Chan, 2003). Furthermore, the success of a reform can only be measured in terms of outcomes; that is, whether the changes result in relevant and useful information being provided to policy makers (politicians). Jorge et al.'s (2016b) study at central government level in Portugal showed that, when the backgrounds of 'information 
brokers' are economics, public administration and law, they tended to prefer to provide cash-based budgetary information.

There is evidence in some historical studies that the professionalization of public sector accountants was linked to the adoption of accrual accounting in the public sector (for example, Baker and Rennie, 2006; Becker et al., 2014; Christensen, 2005, 2006; Chua and Sinclair, 1994). Contrastingly, there was a period when public sector accounting was compared to a battlefield for inter-profession invasions (Christensen and Parker, 2010; Chua and Sinclair, 1994). In the context of public sector accounting reforms, the literature in the following paragraphs shall first deal with collaboration between the underlying professions, and then to conflict.

Jackson and Lapsley (2003) examined the diffusion of accounting innovations in the UK from a communications standpoint. Professional institutions have the potential to act as key agents in the communication process, since they are knowledgeable of new accounting practices and techniques, and can transfer these to others acting in the field, who do not know them, e.g. financial to non-financial managers.

Lüder (1992) pointed out that, when professional bodies, namely standard-setters, have considerable influence, there is a higher propensity for reforms in public sector accounting. The same happens where accountancy staff are trained in the techniques of private sector accounting and are familiar with private sector concepts and practices. Benito et al. (2007) detected an important influence from the accounting profession in countries that are predominantly Anglo-Saxon, for example, the United Kingdom, the United States, Australia and New Zealand. In such countries, even though accounting obligations of local administrations are established by law, these would be highly influenced by 'professional bodies with institutional support that are responsible for establishing accounting standards' (Benito et al, 2007:311). European countries that 
moderately embrace a continental tradition, for example, Portugal, Finland, Spain, Belgium and Italy, have specific accounting standards for their public administrations that are different from those of the business sector, but there still is a significant influence of business accounting standards on the development of public sector accounting standards.

Oulasvirta (2014) similarly concluded that IPSAS may prove to be more influential on accounting institutions in countries that represent the Anglo-Saxon accounting culture. He noted very weak normative forces from the professional associations in Finland, even though they are members of IFAC. Due to New Public Management influences, the Finnish Government introduced commercial bookkeeping as a supplement to its old budgetary accounting practice. However, the long and welldeveloped public sector accounting tradition in Finland resisted pressures to change the domestic accounting institution.

This cultural influence appears to be decreasing. A recent study shows that even some Continental countries have been mobilized towards IPSAS, for example, Portugal, Spain, and Austria (Jorge et al., 2019).

A branch of studies has highlighted an apparent conflict between economists and accountants. For example, Brorstrom (1998) analysed a contest between economists and accountants in Swedish local government accounting. Ryan (1998) considered the relative roles of economists and accountants in the adoption of accrual accounting in the Commonwealth public sector. Christensen et al. (2007) provided details of the interplay of public sector economists and accountants in an international context. Christensen and Parker (2010) presented an interesting case study of the New South Wales Government's decision to adopt full accrual accounting in 1993, illustrating how accrual accounting in the public sector won over NA and the economists, in a contest of ideas about alternative 
reporting methodologies. Eventually, Barton (2011:434) wrapped up the drama by explaining why, in 2008, the Australian government decided to adopt GFS for its GA, and concluded by hoping that 'the benefits from using it will be recognized by other nations and its use becomes widespread'.

Thus, instead of collaboration, there appears to be 'competition for regulatory space' (Hancher and Moran, 1989, and Young, 1994, cited in Heald and Hodges, 2015:994) between two different policy communities, with the policy community for financial reporting mainly consisting of private actors (professional standard-setters, professional accountancy bodies and their members, accounting and audit firms, accounting regulatory bodies, and capital market regulators); while that for NA centring around public actors (national statistics institutions, international/supranational organisations, such as the United Nations, the IMF and the Eurostat, and governments). The common language of government financial reporting is that of accounting, with its internationalised policy community that influences public sector practice through diverse channels (Heald and Hodges, 2015). The common language for NA is economics and statistics. 'The status of statistical accounts stems from their use for the management of public finances in each country and from the dense network of fiscal surveillance' by international and supranational institutions (Heald and Hodges, 2015:996). These two different policy communities have had limited communications with each other over time, but the financial crises and austerity measures has brought them both under the limelight. The EPSAS could be the opportunity to halt, and perhaps reverse, this institutional drift.

\subsection{The link between $\mathrm{GA}$ and $\mathrm{NA}$ - possible convergence?}

Matters concerning the convergence of GA and NA, and specifically if and how GA meets NA requirements, namely considering the ESA rules, have been discussed by both 
academics and professionals (e.g. Cordes, 1996; IFAC-PSC, 2000; Jesus and Jorge, 2010; Jones and Lüder, 1996; Keuning and Tongeren, 2004; Lande, 2000; Montesinos and Vela, 2000). In the EU context, as explained, the relationship between the GA and NA systems is particularly relevant due to the fact that GA figures are the input to NA statistics, in what relates to the General Government Sector outputs. Among these outputs, the public deficit and debt are conspicuous as the reference for the fiscal surveillance regarding the EU convergence criteria, relating to the European Stability and Growth Pact.

The convergence topic is particularly significant in the EU because it was politically established in the Maastricht Treaty that the convergence criteria should be assessed through GFS data in NA (a system already harmonised to all Member States, through ESA), and not from GA data (not yet harmonised among the EU countries) (Jones, 2000b; Jones and Lüder, 1996). It was decided that ratios established in article 104 of the Maastricht Treaty ${ }^{3}$ should be monitored under the Excessive Deficit Procedure Protocol $^{4}$ (Lüder, 2000).

${ }^{3}$ Article 104 of the Maastricht Treaty states the following:

' - The member-States must avoid excessive deficits.

- The Commission has the power to observe the evolution of the budgetary situation and the amount of the governmental debt in the Member States and to monitor:

- whether the ratio of the planned or actual governmental deficit over gross domestic product exceeds a reference value (currently $3 \%$ ), unless the ratio has declined substantially and continuously and reach a level that comes close to the reference value; or alternatively, the excess over the reference value is only exceptional and temporary and the ratio remains close the reference value;

- whether the ratio of governmental debt over gross domestic product exceeds a reference value (currently $60 \%$ ), unless the ratio is sufficiently diminishing and approaching the reference value at a satisfactory pace'.

4 Council Regulation $n^{\circ} 3605 / 93$ modified by Council Regulation $n^{\circ} 475 / 2000$, Commission Regulation (EC) $n^{\circ} 351 / 2002$ and Council Regulation (EC) $n^{\circ}$ 2103/2005. 
According to Lüder (2000), the comparability of convergence criteria ratios requires a certain degree of international harmonisation, and GA in the EU Member States was not meeting this requirement, neither in concepts nor in practices. Consequently, the macroeconomic aggregates, such as the gross domestic product and also the government deficit and debt, should be based on NA.

The diversity of practices applied in GA within EU Member States has been analysed in several studies (e.g. Pina \& Torres, 2003) among which are studies commissioned by the European Commission (e.g. EY, 2012; PwC, 2014). These latter studies concluded that most countries have some approach to IPSAS (namely using accrual or modified accrual basis for financial reporting systems) in parallel with cash accounting at different levels of government; but budgeting systems are cash-based and data to NA comes essentially from these GA budgetary systems (EC, 2013a, 2013b).

The fact that GA data are inputs to NA regarding the General Government Sector, makes differences between the two systems important to be identified, because many of these differences require adjustments when translating data from one system into the other. On this matter, the IPSASB published two seminal reports in 2005 and 2012, identifying main differences and making recommendations to eliminate and reduce the divergences. Table 4 displays the issues referred to in the IPSASB's (2005) report.

\section{[Insert Table 4 here]}

The IPSASB's (2005) report further details the main topics relating to the differences between the two reporting systems, arising from each one's conceptual framework, as those addressed in section 3.1 (IPSASB, 2012a, 2012b). This report classifies the topics causing differences in three categories: (i) resolved issues if countries adopt an IPSAS approach; (ii) issues that present an opportunity to reduce differences (e.g., reporting entity definition, inventory measurement, presentation of financial 
statements, including classification and aggregates, measurement of assets, liabilities and net assets/equity); and (iii) unsolved divergences, because they are due to the different objectives of the two systems. This last category of differences will remain even if IPSAS are adopted, such as those relating to recognition and measurement criteria, and those concerning the reporting boundary in consolidation, which require adjustments that must be managed between the two systems of GA and NA (Dabbicco, 2013; Jorge et al., 2014).

Academic literature (e.g. Cordes, 1996; Jones, 2000b; Jones and Lüder, 1996; Lüder 2000) and other documentary sources (namely, the ESA95 Manual on Government Deficit and Debt, European Commission [Eurostat], 2002) identify the following major topics concerning differences between GA and NA: (i) definition and scope of reporting entity - preparation and disclosure of consolidated financial statements; (ii) recognition of taxes and social contributions - tax credits, tax gap and moment of recording tax revenues; and (iii) the relationship between government and government business enterprises - privatisations, capital injections and government owned enterprises debts and dividends. These differences imply transition adjustments in the data from one system into the other. These adjustments have an impact on the deficit finally reported by Member States to Eurostat. They are presented in the Excessive Deficit Procedure Reporting Tables (set of Tables 2) concerning the several levels of the General Government Sector and are described by each Member State in their Inventories of Sources and Methods (Jesus and Jorge, 2010).

There are other transition debt-related GA-NA adjustments, but they derive from reasons other than those mentioned above. They are presented in Table 3 of the Excessive Deficit Procedure reporting tables, but have received less focus in both professional reports and the literature. This may be because the deficit, at least in the first decade of the fiscal surveillance, was considered to be of greater importance than government debt, 
which gained attention only after the sovereign debt crisis around 2010 (e.g. the "EU multipack", EC, 2013d). However, some literature must be highlighted.

With reference to the United Kingdom's Whole of Government Accounts, Chow et al. $(2007,2008)$ and Heald and Georgiou $(2009,2011)$ examine the effect on reporting public debt due to the different consolidation rules in ESA and GA. The authors found that the United Kingdom's Whole of Government balance sheet was not as 'whole' as it purported to be, because the United Kingdom's Treasury applied NA concepts of consolidation. According to Heald and Georgiou (2011), reconciliation statements between GA and NA values of debts (and deficits) are important disclosures for fiscal transparency and accountability purposes. However, Jones and Caruana (2015) criticise the actual meaning and usefulness of such reconciliations, stating that their purpose could be to provide comfort to the preparers. Jones and Caruana (2014) refer specifically to the treatment of pensions of public service employees, highlighting that, while the United Kingdom's Whole of Government Accounts include the net public service pension liability for public sector employees, such liabilities are not included in public sector debt statistics as reported in the NA. Dabbicco (2018) points out that, according to ESA2010, stocks of government unfunded schemes are not recorded in the core NA, therefore, related obligations are not included in NA measures of total financial liabilities.

When exploring the financial management aspects of public debts, Biondi (2016a, 2016b) and Biondi and Boisseau-Sierra (2017a, 2017b) also refer to different valuations of debt in GA and NA. Recently, Dabbicco (2018), while analysing conceptual differences between measures of debt, discusses an approach to reconciliation and possible convergence between statistical and accounting frameworks in this respect.

GA-NA deficit-related adjustments might be classified into two major groups that imply standardised adjustment procedures: (i) cash-accrual adjustments for taxes, social 
contributions, primary expenditure and interest; and (ii) reclassification of some transactions, namely capital injections in state-owned corporations, dividends paid to General Government Sector entities, military equipment expenditure, and EU grants (Jesus and Jorge, 2014).

Jesus and Jorge (2010) and Dasí et al. (2011, 2013) grouped the main deficitrelated GA-NA adjustments categories as displayed in Table 5, associating them with the conceptual framework differences between the two systems. These deficit-related adjustment categories, which correspond to those in the Excessive Deficit Tables 2, have been analysed in several academic studies, namely by Jorge et al. (2014), Dasí et al. (2011, 2013, 2016) and Jesus and Jorge $(2014,2015,2016)$, focusing on their diversity and materiality in the Excessive Deficit Procedure reporting and their consequent implications on the deficit reliability among Member States.

\section{[Insert Table 5 here]}

Dabbicco and D'Amore (2016) highlighted some conceptual and practical issues to be considered when addressing the link between macroeconomic surveillance (using NA figures) and General Purpose Financial Reports, analysing some of the differences in order to compare GFS and IPSAS indicators. In turn, Dasí et al. (2016) provided an analysis of standardised reporting under ESA and budgetary accounting. These studies have also tried to assess the convergence level between GA and NA systems, discussing whether the evident lack of convergence is indeed a problem susceptible to be solved or not.

Furthermore, considering the situation of full accrual (for example IPSAS) implementation in an EU Member State, Dabbicco (2013) presented a case showing the potential issues to be resolved in Excessive Deficit Tables 2, in order to reconcile accrual accounting (GA) with ESA. Such a reconciliation would include adjustments to get the 
budgetary report on a full accrual basis (when the working balance is compiled under a cash or mixed basis), and those necessary to reconcile the accruals in GA with the ESA. The case detailed these reconciliations in adjustments to: financial transactions, time of recording and other adjustments (such as off-budget transactions), reporting boundary, revaluations, interests, investments, military expenditure, pensions and other specific transactions and accruals for taxes. In this line, the studies by Jorge et al. (2016) and Dasí et al. (2016) show that, even if Member States' GA systems come to approach IPSAS, the materiality and diversity of GA-NA deficit-related adjustments continue to be relevant, and the GA-NA convergence level even reduces in several EU countries.

The main conclusions from the above-referred studies may be summarised as follows:

- The accuracy of NA data regarding the main aggregates to assess EU convergence criteria depends on the diversity and materiality of GA-NA deficit-related adjustments and the respective treatment when translating the data of one system into the other;

- It is important to reduce diversity and materiality of the deficit-related GA-NA adjustments and also to harmonise them across Member States, in order to achieve reliability and comparability regarding the fiscal discipline assessment among EU countries;

- The reduction of these adjustments is an important step towards convergence between GA and NA, increasing the alignment of the two systems and improving NA information accuracy in what concerns the General Government Sector.

- GA-NA convergence, although apparently needed, might not lead to the desired result and, therefore, considerable differences will continue between GA and NA systems, 
even if Member States move towards IPSAS, or any IPSAS-based GA systems, namely EPSAS (Sforza and Cimini, 2017).

Overall, these studies also highlight that convergence might be better achieved if countries effectively implement accrual-based budgeting as a subsystem in GA.

\subsection{The role of budgetary accounting and auditing}

As a consequence of its evolution, the scope of GA reporting contains three different types of information (Pina and Torres, 2003): (i) budgetary (cash or accrual-based); (ii) accrual-based financial information; and (iii) non-financial information. In fact, the 'scope of governmental accounting' may be seen as narrower or broader, respectively focusing on financial accounting or instead, encompassing also budgeting, financial reporting and auditing (Chan et al. 1996). It follows that 'financial accounting' and 'budgeting' should be distinguished, as they may have different functions, and may have different underlying bases of accounting. In fact, despite some similarities, budgeting and accounting have also significant differences:

... both produce financial information; both are a kind of fiscal language, but budgeting and (financial) accounting might differ in focus, time perspective, their conceptual model, their recording system, and measurement method (Chan and Heiling, 2012:25).

The emphasis on a legal rather than a more business-style approach prevailing in EU countries, such as Italy, Portugal, Germany and France, led to substantial differences in the role of 'budgeting' and 'financial accounting' as components of GA. Although budgeting might address both ex-ante (estimations) and ex-post (actuals) perspectives, only the latter - the so-called 'budgetary accounting and reporting' - forms part of GA. 
Given that, in the majority of EU countries, budgetary reporting is still the main source of information for the NA figures in what concerns the General Government Sector, the focus for the convergence between GA and NA should be the budget and the budgetary reporting system (Jones, 2000b). Accordingly, Jorge et al. (2014:34) showed that 'changing GA reporting basis into accruals reduces [GA-NA deficit-related] adjustments' materiality and diversity', therefore the accrual basis should be adopted 'in both [GA] budgetary and financial systems'. In the relationship between GA and NA, budgets and budgeting are, according to Jones (2014:73), 'the practical bridge' linking the accounting and economics concepts.

Jesus and Jorge (2015) and Dasí et al. (2016) emphasise that the convergence between GA and NA systems is relevant to assure reliability and accuracy of the NA output data that sustain EU fiscal and monetary policies. Considering that the use of full accrual basis for the majority of transactions is compulsory in NA for all Member States, GA reforms in progress in the European context, moving from cash-based to accrualbased accounting systems, should embrace the whole of GA subsystems, namely including budgetary accounting and reporting, as this continues to be the main source of data from GA to NA.

The literature is scarce in what concerns the role of auditing in the GA-NA relationship. However, it is overall recognised that, within the GA framework, budgetary and financial reporting are subject to some form of auditing. Budgetary reporting is normally subject to regularity/compliance audits by Supreme Auditing Institutions, according to audit standards set by the International Organisation of Supreme Audit Institutions. Financial statements are also subject to audit, for true and fair presentation, often by professionals in private audit firms, according to International Standards on 
Auditing issued by the IFAC. On the other hand, National Accounts are not audited. Eurostat carries out 'missions' in Member States to check the conversion process applied from GA to NA, but there does not appear to be a formal structure in place for such procedure (ECA, 2012a).

In 2012, the European Court of Auditors issued statements about the (limited) role of Supreme Audit Institutions in the process of Member States transferring data to Eurostat (ECA, 2012b). Some academic papers also refer to NA audit. For example, Jones (2000b, 2014) says that National Accounts are not auditable. Jones and Caruana (2015) propose that the Maastricht criteria should be based on GA because this is audited, whereas NA figures are not. More recently, Caruana and Grima (2019) recommend that the translation of GA data to NA should be audited by Supreme Audit Institutions.

\section{Analysis}

Critical events, such as the issue of a new ESA, the harmonisation of GA with business accounting (notably through IPSAS), and the sovereign debt crisis, have incited discourse on important topics of concern, which are relevant for the EPSAS project.

\section{[Insert Figure 1 here]}

Figure 1 displays a timeline highlighting the main milestones affecting the major issues about GA, NA and the relationship between the two systems. The milestones and related issues dealt with in both professional reports and academic literature over the last $20+$ years are elaborated in Table 6.

[Insert Table 6 here] 
From the analysis in Table 6, one can deduce that practitioners are more pro-active while academics appear to be more reactive to the subject GA versus NA. This makes sense in two ways. First of all, being more hands on, practitioners identify the issues, which then raise the debate by academics - both on the issues themselves, and also on how the practitioners are perceiving or dealing with them. In other words, academics address more conceptual issues rather than practical. Secondly, this apparent delayed response from academics is only natural due to the slow process required for the publication of scientific papers.

The following sections present an analysis of the findings of section 3, taking into consideration the issues highlighted in Table 6 .

\subsection{The Conceptual Frameworks}

The co-existence of the two (competing) reporting systems in the public sector has been characterised by development of the respective techniques (Jones 2003), which were well known by each community but somewhat hardly documented before the 1990s. Slowly, differences in approaches have been addressed at conceptual (and technical) level by literature of both practitioners and academics over the last two decades. Notably, the emergence of a need to reduce the statistical burden, a better integration between various statistical and administrative sources and the improvement of quality in statistical data in terms of harmonisation and transparency, took the scene, as highlighted by international organisation reports, national statistics institutions and academic studies, with an increased focus paid from the middle 1990s to the theme of 'accounting and EU statistics'. Particularly, statisticians' involvement in business accounting standards (for example, in UK and France) initiated the consideration of such conceptual (and technical) 
issues, raising awareness on the concepts underpinning GA and NA and their complex relationship.

The internationalisation and standardisation of GA under the IFAC - Public Sector Committee/IPSASB also led to the emergence of an explicit conceptual framework for GA, that added to the already standardised and harmonised NA conceptual framework. These conceptual frameworks have proved relevant to provide the basis for a better understanding of the accounting and statistical standards, and guidance on the general underlying principles. The design and subsequent analysis of these conceptual frameworks included reflections on the needs of information of users, and on the nature and the extent of the differences between them. This allowed comparison, notably in terms of objectives, scope, recognition and measurement criteria, as well as of qualitative characteristics in the two reporting systems.

\subsection{Institutionalisation and the underlying professions}

Even before the IFAC's Public Sector Committee was established in 1996, academic papers dealt with accrual accounting reforms for GA. This is understandable in view of the discussions by professional bodies that subsequently led to the institutionalisation of public sector accounting standards. When studying accrual accounting reforms for GA, academics discussed technicalities also in view of public sector peculiarities, and took as well into consideration the various social, political and legal structures found in different jurisdictions. Moreover, the academic papers tended to focus more on the actors involved in such reforms, for example the roles of public service officials and accountants, and the professional interests and normative power of the latter. In view of the technical developments in NA, which included an intensification of accrual methodology linked to 
business accounting, academics started also exploring the relationships between accountants and economists due to the GA and NA overlap on accrual concepts.

As practitioners started discussing the harmonisation process of GA and NA, particular academics showed an in-depth understanding of both NA and GA, and, unlike the bulk of practitioners' studies, did not lose sight of the importance of budgeting in GA. They immediately included government budgeting in the equation, and did not treat it as an afterthought.

Moreover, the European Commission's need to improve the quality of NA was met with the IPSASB's study on converging IPSAS with GFS, and the development of IPSAS 22 - Disclosure of Information About the General Government Sector. Subsequently, academic studies on the potential role of IPSAS for improvement in NA reliability started emerging. There were also some papers on NA per se; however, academic papers still focused on the institutionalisation of GA and the roles of the actors involved in GA reform in the specific public sector context.

The onset of the financial crisis in 2008, which in the EU culminated in the «Six Pack» legislation, led academic papers to focus on NA and IPSAS for GA, with some being rather critical, while others took a normative view of IPSAS. Once again, academics demonstrated a holistic view of GA specific needs, while unveiling the underlying interests of the accounting profession. This trend in academic papers intensified during the ensuing period (as from 2014), when the European Commission demonstrated serious intentions about the consideration of IPSAS for the development of EPSAS, and is still evident up to time of writing.

\subsection{Convergence and adjustments}

Within the European context, the link between GA and NA has been particularly considered from the ESA95 implementation, firstly by academics, who discussed the 
main conceptual differences among the two systems and the pertinence of their convergence. This discussion became particularly relevant from the moment when it was politically decided that the assessment of the Maastricht convergence criteria should be based on NA data.

As GA information is the source of NA, professional reports focused on NA and then came to discuss technical procedures to translate the data. From middle 2005, efforts for international harmonisation in GA gained particular importance when the IPSASB started to address standards on public sector specific topics and realised that IPSAS were seen as a possible solution to improve convergence between GA and NA. By this time, professional reports addressed issues that needed to be treated in order to harmonise GA and NA concepts and criteria, so as to contribute for increasing the reliability of the outputs reported by NA.

A few years later, already within the context of a revised ESA2010, academics picked up again the GA-NA convergence matter, highlighting its relevance for the credibility of the information concerning the deficit and debt figures finally reported by Member States. They have tried to provide a deeper understanding of the differences between GA and NA, developing detailed and quantitative analysis, assessing the consequent adjustments, their management and impact on the GA-NA data translation process.

\subsection{Role of budgetary accounting and auditing}

Around 2000, academics started to discuss the role of budgeting as the bridge between GA and NA. They return to the subject 15 years later, already considering the ESA2010 and in the advent of the EPSAS project. In both moments, the particular matter under discussion was the observation that, within the GA international harmonisation process and the possible convergence with NA, budgetary accounting and reporting cannot be set 
aside as this is still the main source of data for NA regarding the government sector. So, attention was called to the need for the accrual basis to be considered in budgetary reporting or the GA-NA data adjustments to be somehow reduced and harmonised. In some countries, like in the UK, this was a big issue - the budget now includes a reconciliation between GA and NA figures.

Professional reports, however, did not address the matter so soon. Only in 2006, IPSAS 24 - Presentation of Budget Information in Financial Statements was issued and, within the EU context, the awareness that fiscal targets assessed on the basis of NA required more reliable budgetary reporting from GA happened between 2011 and 2013 within the «Six Pack» legislation.

In the last five years, the role of auditing has been somehow considered in the debate. While EU authorities have acknowledged the minimal role of auditing in NA, academic literature has called attention to the need of increasing the role of auditing in the process of translating data from GA into NA, in order to assure reliability of the data finally reported in NA, hence reassuring a trustworthy basis for EU fiscal and monetary policies.

\section{Conclusion}

GA serves different purposes and perspectives compared to NA. These different perspectives are commonly accepted, leading to, among others, different scope of the reporting entities, different definitions of the elements related to financial performance and financial position and different measurement bases, therefore affecting the bottomline results and financial position disclosed by the two reporting systems. Alignment and harmonisation projects have been of great interest in Europe in the last 20+ years, highlighting that it is necessary to manage the continued existing differences between GA 
standards and ESA standards regarding the General Government Sector. The EPSAS development should take into consideration that GA-NA conceptual differences are likely to remain, and should be managed in a reliable way when translating the data between the two reporting systems. Thus, illustrative charts of accounts and bridge tables may prove to be useful at the technical level (PwC, 2017).

The development of EPSAS should not overlook the important role of the actors involved in GA and NA. The literature on institutional developments of GA and NA and the various studies regarding the underlying professions, lead us to suggest that increased collaboration between professions would be fruitful. Together with the insightful contribution of academics in the field of public sector accounting, a specific interdisciplinary professional degree could be developed with the aim of preparing professionals who have a holistic understanding of GA and NA. In this way, public administrators can be effective professionals in public finance.

Moreover, such collaboration would also be crucial to guide the development of EPSAS to result in more effective and acceptable accounting standards. Various academic literature highlights the futility of attempting to adopt private sector accounting practices in the public sector context. This literature was not reviewed in this paper because it is beyond its scope. However, if EPSAS shall proceed on the basis of IPSAS, the difficulties that such literature emphasises need to be borne in mind. The development of EPSAS needs to be a collaborative multi-disciplinary effort, and not an imposition of one's particular norms and practices over another.

Nowadays, the ongoing establishment of common accounting standards for Member States - the EPSAS project - seems to be the first big step towards a harmonised system in GA among EU countries. This project must also consider the convergence problems arising from the differences between GA and NA systems and, consequently, 
pay attention to the need of introducing accrual accounting not only in financial reporting, but also in budgetary accounting and reporting in order to make this also comparable and reconcilable. Therefore, the alignment between budgetary reporting and NA is particularly important if the former continues to be the main source of data to the latter regarding the General Government Sector; the alternative would be that the source for NA becomes accrual-based whole-of-government financial accounts.

Improving accruals in financial and budgetary subsystems towards an overall harmonised GA system is a relevant issue for assessing Member States' financial performance, namely by the capital markets.

Concerning NA policy-makers, it is also relevant to consider a common framework to standardise and harmonise the adjustments from GA to NA and the accounting treatment when translating data from one system into the other. This is of utmost importance, despite the existent Consolidated Inventory of Source and Methods and the Excessive Deficit Procedure tables each country discloses; while these Inventories merely explain each country's particular and dissimilar accounting treatments and procedures, a common framework should be mandatorily followed by all Member States.

Considering that Member States might use the technical GA-NA adjustments to window-dress their accounts in order to be in line with the convergence criteria, EU policy-makers should rely on a framework, such as the above referred, which should reduce the possibilities for countries to be somehow creative in adjustment management, and consequently increasing the quality of the information managed and reported. In addition, within the EPSAS project, the standards should only allow very few options regarding recognition and measurement criteria, in order to get more harmonised GA data. 
Finally, it is pertinent to question whether EPSAS are, by themselves, a tool to reduce the GA-NA divergences and to increase the Maastricht criteria reliability, especially in face of the major investment of resources their implementation potentially requires, also including a cultural change. Besides the quality of the primary sources, only proper audit procedures can provide a degree of reliability. Audit would be facilitated with proper standards (both reporting standards and audit standards). Therefore, the EPSAS should be holistic in this sense, also addressing both budgetary accounting and audit processes.

\section{References}

Ahmed, J.U. (2010). Documentary Research Method: New Dimensions. Indus Journal of Management \& Social Sciences, 4(1), 1-14.

Baker, R., \& Rennie, M. (2006). Forces leading to the adoption of accrual accounting by the Canadian Federal Government: an institutional perspective. Accounting Perspectives, $5(1), 83-112$.

Ball, I. (2011). What Role Can Accounting Standards for the Public Sector Play in Promoting Government Transparency? World Bank Government Borrowers Forum, $11^{\text {th }}$ May 2011, Chile. Retrieved from http://www.ifac.org/news-events/2011-05/what-role$\underline{\text { can-accounting-standards-public-sector-play-promoting-government-trans }}$

Barton, A. (2011). Why Governments should use the General Finance Statistics Accounting System. Abacus, 47(4), 411-455.

Becker, S., Jagalla, T., \& Skærbæk, P. (2014). The translation of accrual accounting and budgeting and the reconfiguration of public sector accountants' identities. Critical Perspectives on Accounting, 25(4-5), 324-338. 
Benito, B., Brusca, I., \& Montesinos, V. (2007). The harmonization of government financial information systems: The role of the IPSASs. International Review of Administrative Sciences,73(2), 293-317.

Biondi, Y. (2016a). Accounting representations of public debt and deficits in European central government accounts: An exploration of anomalies and contradictions. Accounting Forum, 40(3), 205-219.

Biondi, Y. (2016b). The HM 'Treasure's Island': The Application of Accruals-based Accounting Standards in the UK Government. Accounting in Europe, 13(1), 81-102.

Biondi, Y. \& Boisseau-Sierra, M. (2017a). Financial Sustainability and Public Debt Management in Central Government. In: Rodríguez Bolívar, M. (ed) Financial Sustainability in Public Administration. Palgrave Macmillan, Cham.

Biondi, Y. \& Boisseau-Sierra, M. (2017b) Pension Obligations in the European Union: A Case Study for Accounting Policy. Accounting, Economics, and Law, 7(3), 1-27.

Bos, F. (1995). Economic Theory and National Accounting, Statistics Netherlands Nr. NA-075 1995.

Bos, F. (1996). The Future of the National Accounts, National Accounts Occasional Paper No. 84. Available at SSRN: https://ssrn.com/abstract=1033311 or http://dx.doi.org/10.2139/ssrn.1033311

Bos, F. (2007). Use, misuse and proper use of national accounts statistics, MPRA Paper 2576, University Library of Munich, Germany. 
Bos, F. (2008). Uses of national accounts: History, international standardization and applications in Netherlands. Available at SSRN: https://ssrn.com/abstract=1153354 or http://dx.doi.org/10.2139/ssrn.1153354

Brorstrom, B. (1998). Accrual Accounting, Politics and Politicians. Financial Accountability and Management, 14(4), 319-333.

Brusca, I., Caperchione, E., Cohen, S., \& Manes Rossi, F. (2015). Public Sector Accounting and Auditing in Europe: The Challenge of Harmonization. Basingstoke: Palgrave Macmillan.

Caruana, J., \& Grima, L. (2019). IPSAS, ESA and the Fiscal Deficit - a question of calibration. Public Money \& Management, 39(2), 121-130.

Chan, J. (2003). Government Accounting: An Assessment of Theory, Purposes and Standards. Public Money \& Management, 23(1), 13-20.

Chan, J., Jones, R., \& Lüder K. (1996). Modelling Governmental Accounting Innovations: An Assessment and Future Research Directions, Research in Governmental and Nonprofit Accounting, 9, 1-20.

Chan, J., \& Heiling, H. (2012). From Servant or Master? On the Evolving Relationship between Accounting and Budgeting in the Public Sector. 2012 Yearbook of the Swiss Society of Administrative Sciences, 23-38.

Christensen, M. (2005). The 'Third Hand': private sector consultants in public sector accounting change. European Accounting Review, 28(3), 447-474. 
Christensen, M. (2006). On public sector accounting change: epistemic communities, consultants, naïve officials and a reply to Humphrey. European Accounting Review, 15(2), 289-296.

Christensen, M., \& Parker, L. (2010). Using Ideas to Advance Professions: Public Sector Accrual Accounting. Financial Accountability and Management, 26(3), 246-266.

Christensen, M., Newberry, S., \& Potter, B. (2007). The Role of Epistemic Communities in Bringing Widespread Accounting Change: Developing Global Accounting Reforms for Public Sector Entities. in APIRA2007 Proceedings.

Christiaens, J., Vanhee, C., Manes Rossi, F., Aversano, N, \& Cauwenberge, P. V. (2015). The effect of IPSAS on reforming governmental financial reporting: An international comparison. International Review of Administrative Sciences, 81(1), 158-177.

Chow, D., Humphrey, C., \& Moll, J. (2007). Developing whole of government accounting in the UK: Grand claims, practical complexities and a suggested future research Agenda. Financial Accountability and Management, 23(1), 27-54.

Chow, D., Humphrey, C., \& Moll, J. (2008). Whole of government accounting in the UK. Project Report. Association of Chartered Certified Accountants (ACCA), London.

Chua, W. F., \& Sinclair, A. (1994). Interests and the profession-state dynamic: Explaining the Emergence of the Australian Public Sector Accounting Standards Board. Journal of Business Finance and Accounting, 21, 669-705.

Cordes, U. (1996), The 1995 European System of National Accounts (ESA), Governmental Accounting Reforms and the Government Sector's Micro-Macro Link, 
Recent Developments, in Klaus Lüder (Ed.), Comparative International Governmental Accounting Research, Speyerer Forschungsberichte, 159, 1-20.

Dabbicco, G. (2013). The reconciliation of primary accounting data for government entities and the balances according to statistical measures: the case of the European Excessive Deficit Procedure Table 2. OECD Journal on Budgeting, (1), 31-43.

Dabbicco, G. (2015a). The Impact of Accrual-Based Public Accounting Harmonization on EU Macroeconomic Surveillance and Governments' Policy Decision-Making. International Journal of Public Administration, 38(4), 253-267.

Dabbicco, G. (2015b). The boundary of the public sector in National Accounts versus IPSAS. Statistika, Statistics and Economy Journal, 2, 17-32.

Dabbicco, G. (2016) A comparison of Government Accounting and Government Finance Statistics, Doctoral Thesis in Economics of public sector entities, University of Naples "Parthenope", Italy.

Dabbicco, G. (2018). A comparison of Debt Measures in Statistics and Financial Statements. Public Money \& Management. 38(7), 511-518

Dabbicco, G., \& D’Amore, M. (2016). Debate: Accounting for Macroeconomic Surveillance in Europe. Public Money \& Management, 36(3), 162-164.

Dasí, R. (2011), El Pacto de Estabilidad y Crecimiento ante la crisis. Determinación y seguimiento del Déficit Público de los estados Miembros de la Unión Europea. Revista Española de Control Externo, XIII(39), 65-104. 
Dasí R. M., Montesinos, V., \& Murgui, S. (2013) Comparative Analysis of Governmental Accounting Diversity in the European Union. Journal of Comparative Policy Analysis: Research and Practice, 15(3): 255-273.

Dasí R. M., Montesinos, V. \& Murgui, S. (2016). Government Financial Statistics and Accounting in Europe: is ESA2010 improving convergence? Public Money \& Management, 36(3), 165-172.

Djelic M.L., \& Quack S. (2008). Institutions and transnationalization. In: Greenwood, R., Oliver, C., Suddaby, R., \& Sahlin, K., (Eds), The SAGE handbook of organizational institutionalism. London: Sage Publications.

EC (Eurostat) (2002). ESA95 Manual on Government Deficit and Debt (EMGDD). Luxembourg: Office for Official Publications oh the European Communities.

EC (2013a). Commission staff working document, accompanying the report from the Commission to the Council and the European Parliament. Towards implementing harmonised public sector accounting standards in Member States, The suitability of IPSAS for the Member States, [SWD(2013) 57 final], Brussels, Belgium, March 6.

EC (2013b). Towards implementing harmonised public sector accounting standards in member states, the suitability of IPSAS for the member states. Report from the Commission to the Council and the European Parliament [COM(2013) 114 final], Brussels, Belgium, March 6.

EC (Eurostat) (2013c). European system of accounts (ESA 2010), Luxembourg. 
ECA (European Court of Auditors) (2012a). Did the commission and Eurostat improve the process for producing reliable and credible European statistics? Special Report No.12.

EC (Eurostat), (2013d), Beyond the six pack and two pack: Economic governance explained, Reference: MEMO/13/318, Brussels.

ECA (European Court of Auditors), (2012b). Resolution CC-R-2012-02 on Supreme Audit Institutions' cooperation with Eurostat and National Statistical Institutions. Retrieved from http://eca.europa.eu/portal/pls/portal/docs/1/18138743.PDF

EU (2011). Council Directive 2011/85/EU, on requirements for budgetary frameworks of the Member States, L306/41, Official Journal of the EU.

European Parliament (2011). Report on the proposals for the budgetary framework for the Member States (6 May 2011, A7-0184/201)

EY (2012). Overview and comparison of public accounting and auditing practices in the 27 EU Member States. Retrieved from http://www.ec.europa.eu

Grossi, G., \& Soverchia, M. (2011). European Commission Adoption of IPSAS to Reform Financial Reporting, Abacus, 47(4), 525-552.

Guthrie, J. (1998). Application of accrual accounting in Australian public sector: rhetoric or reality? Financial Accountability and Management, 14(1), 1-19.

Heald, D., \& Georgiou, G. (2009). Whole of government accounts developments in the UK: conceptual, technical and timetable issues. Public Money \& Management, 29(4), $219-227$. 
Heald, D., \& Georgiou, G. (2011). The Macro-Fiscal Role of the U.K. Whole of Government Account. Abacus, 47(4), 446-476.

Heald, D., \& Hodges, R. (2015). Will “austerity” be a critical juncture in European public sector financial reporting? Accounting, Auditing \& Accountability Journal, 28(6), 9931015.

Heiling. J., Schuhrer, S., \& Chan, J. (2013). New development: Towards a grand convergence? International proposals for aligning government budgets, accounts and finance statistics. Public Money \& Management, 33(4), 297-303.

Hsieh, H. F., \& Shannon, S. E. (2005). Three approaches to qualitative content analysis. Qualitative Health Research, 15(9), 1277-1288.

IFAC-PSC - International Federation of Accountants, Public Sector Committee (2000), Study 11, Governmental Financial Reporting: Accounting Issues and Practices, New York.

International Monetary Fund (IMF), et al. (2006). Task force on harmonization of public sector accounting - TFHPSA - Final report, United States.

IPSASB (2005). International Public Sector Accounting Standards (IPSASs) and Statistical Bases of Financial Reporting: An Analysis of Differences and Recommendations for Convergence. IFAC, New York.

IPSASB (2012a). IPSASs and Government Finance Statistics - Consultation Paper, New York. Retrieved from https://www.ifac.org/public-sector/projects/alignment-ipsas-andgovernment-finance-statistics-reporting-guidelines 
IPSASB (2012b). Alignment of IPSAS and Government Finance Statistics Reporting Guidelines, Project completed. Retrieved from https://www.ifac.org/publicsector/projects/alignment-ipsas-and-government-finance-statistics-reporting-guidelines

IPSASB (2013). IPSASs and GFS Reporting Guidelines: Review of Responses.

IPSASB (2014a). Process for considering GFS reporting guidelines during development of IPSAS, Policy Paper. New York. Retrieved from http://www.ifac.org

IPSASB (2014b), The Conceptual Framework for General Purpose Financial Reporting by Public Sector Entities. IFAC, New York.

IPSASB (2014c), Handbook of International Public Sector Accounting Pronouncements. Jun 01, 2014, New York, retrieved from www.ifac.org

Jackson, A., \& Lapsley, I. (2003). The diffusion of accounting practices in the new “managerial” public sector. International Journal of Public Sector Management, 16(5), $359-372$.

Jesus M. A., \& Jorge, S. (2010). From Governmental Accounting to National Accounting: implications on the Portuguese Central Government deficit; Notas Económicas, 31, 2446.

Jesus M. A., \& Jorge, S. (2014). From governmental accounting into national accounts: adjustments diversity and materiality with evidence from the Iberian countries' central governments. Innovar - Journal of Administrative and Social Sciences, 24(54), 121-138. 
Jesus, M.A., \& Jorge, S. (2015). Governmental budgetary reporting systems in the European Union: is the accounting basis relevant for the deficit reliability? International Review of Administrative Sciences, 81(1), 110-133.

Jesus, M. A., \& Jorge, S. (2016). Accounting basis adjustments and deficit reliability: evidence from southern European countries. RC-SAR - Revista de Contabilidad (Spanish Accounting Review), 19(1), 77-88.

Jones, R. (2000a). Public versus Private: The Empty Definitions of National Accounting. Financial Accountability and Management. 16(2), 167-178.

Jones, R. (2000b). National Accounting, Government Budgeting and the Accounting Discipline. Financial Accountability and Management, 16(2), 101-116.

Jones, R. (2003), Measuring and reporting the Nation's finances: statistics and accounting. Public Money \& Management, 23(1), 21-28.

Jones, R. (2014). Management of Government within Two Different Exogeneous Financial Metrics: An unfamiliar Context for Research and Teaching, in Bourmistrov. A., \& Olson, O. (Eds.). Accounting, Management Control and Institutional Development. Cappalen Damm Akademisk, Oslo, 63-79.

Jones, R., \& Caruana, J. (2014). A Perspective on the Proposal for European Public Sector Accounting Standards in the Context of Accruals in UK Government. Accounting, Economics, and Law, 4(3), 265-282.

Jones, R., \& Caruana, J. (2015). EPSAS - worrying the wrong end of the stick? International Journal of Public Administration, 38(4), 240-252. 
Jones, R., \& Lüder, K. (1996). The relationship between National Accounting and Governmental Accounting: State of the art and comparative perspectives. Research in Governmental and Non-Profit Accounting, 9, 59-78.

Jorge, S., Jesus, M. A., \& Laureano, R. (2014) Exploring determinant factors of differences between Governmental Accounting and National Accounts budgetary balances in EU Member States. Transylvanian Review of Administrative Sciences, 10(44), 34-54.

Jorge, S., Jesus, M. A., \& Laureano, R. (2016a). Governmental Accounting Maturity Towards IPSASs and the Approximation to National Accounts in the European Union. International Journal of Public Administration, 39(12), 976-988.

Jorge, S., Jesus, M. A., \& Nogueira, S. (2016b). Information Brokers and the use of budgetary and financial information by politicians: the case of Portugal. Public Money \& Management, 36(7), 515-520

Jorge, S., Brusca, I., \& Nogueira, S.P. (2019). Translating IPSAS into National Standards: An Illustrative Comparison between Spain and Portugal, Journal of Comparative Policy Analysis: Research and Practice, DOI: $\underline{10.1080 / 13876988.2019 .1579976}$

Keuning, S., \& Tongeren, D. (2004). The relationship between government accounts and national accounts, with special reference to The Netherlands. Review of Income and Wealth, 50(2), 167-179.

Khan, A., \& Mayes, S. (2009). Transition to Accrual Accounting. IMF Fiscal Affairs Department, Technical Notes and Manuals 09/02. 
Lalibertè, L. (2004). The Relationship between Macroeconomic Statistics Guidelines and accounting standards. WP/04/233. IMF Working Paper. Statistics Department.

Lande, E. (2000). Macro accounting and accounting relationships in France. Financial Accountability and Management, 16(2), 151-165.

Lequiller, F. (2015). Towards convergence between government finance statistics and public sector accounting standards, EURONA 1/2015.

Lequiller, F., \& Blades, D. (2006, 2014). Understanding National Accounts. OECD, Adapted and translated from Manuel de comptabilité nationale published by Economica, France 49 rue Héricart, 75015, Paris, Retrieved from http://www.economica.fr/

Lüder, K. (1992). A Contingency Model of Governmental Accounting Innovations in the Political-Administrative Environment. Research in Governmental and Nonprofit Accounting, 7, 99-127.

Lüder, K. (2000). National accounting, governmental accounting and cross-country comparisons of governmental financial condition. Financial Accountability and Management, 16(2), 117-128.

Manes Rossi, F., Cohen, S., Caperchione, E., \& Brusca, I. (2016). Harmonizing public sector accounting in Europe: Thinking out of the box. Public Money \& Management, 36(3), 189-196.

Martí, C. (2006). Accrual budgeting: Accounting treatment of key public sector items and implication for fiscal policy. Public Budgeting \& Finance, 26(2), 45-64. 
McCulloch, G., \& Richardson, W. (2000). Historical research in educational settings. Buckingham: Open University Press.

Monducci, R., Dabbicco, G., Di Francescantonio, T., Filiberti, S. Sansone, U., \& Sanzo, R. (2003). Prime esperienze sull'utilizzo integrato di fonti statistiche e amministrative per la produzione di statistiche strutturali sui risultati economici delle imprese, Chapter in Temi di ricerca ed esperienze sull'utilizzo a fini statistici di dati di fonte amministrativa, (Eds by Falorsi P.D., Pallara A., Russo A). Collana Economia - Franco Angeli editore.

Montesinos, V., \& Vela, J. M. (2000). Governmental accounting in Spain and the European Monetary Union: A critical perspective. Financial Accountability and Management, 16(2), 129-150.

Müller-Marqués Berger, T. (2009). IPSAS Explained, Ernst \& Young, West Sussex: Wiley.

Onida, P. (2004), Economia d'azienda, UTET, Torino, Italy

Oulasvirta, L. (2014). The reluctance of a developed country to choose International Public Sector Accounting Standards of the IFAC. A critical case study. Critical Perspectives on Accounting, 25, 272-285.

Pina, V., \& Torres, L. (2003). Reshaping public sector accounting: An international comparative view. Canadian Journal of Administrative Sciences, 20(4), 334-350.

Prior, L. (2003). Using Documents in Social Research. London: Sage.

PWC. (2014). Collection of information relating to the potential impact, including costs of implementing accrual accounting un the public sector and technical analysis of the 
suitability of individual IPSAS standards, PWC, Belgium. Retrieved from http://www.pwc.be

PwC. (2017). Member States' approaches to harmonising charts of accounts for national purposes with a view to financial reporting requirements under the future European Public Sector Accounting Standards (EPSAS), November. Retrieved from https://circabc.europa.eu

Rocher, S. (2010). The Beginning of International Public Accounting Standard-Setting: A Short History. Original version 'La genèse de la normalisation internationale de la comptabilité publique'. Revue Française de Comptabilité, 438, 38-41. English version retrieved from http://www.univ-angers.fr/_attachments/mypage-sebastien-rocher$\underline{\text { fr/ROCHER_Brief } \% 2520 \text { History\%2520IPSASB.pdf?download=true }}$

Ryan, C. (1998). The Introduction of Accrual Reporting Policy in the Australian Public Sector: An Agenda Setting Explanation. Accounting, Auditing and Accountability Journal, 11(5), 518-539.

Sforza, V., \& Cimini, R. (2017). Central government accounting harmonization in EU member states: will EPSAS be enough? Public Money \& Management, 37(4), 301-308

Tily, G. (2009). Keynes and the financing of public works expenditures, Post Keynesian Study Group, retrieved from

http://www.postkeynesian.net/members/working\%20papers/Tily\%2025082009.pdf

Tily, G. (2010 [2007]). Keynes Betrayed: The General Theory, the Rate of Interest and 'Keynesian’ Economics, Basingstoke: Palgrave Macmillan. 
United Nations (UN) (2000). Links between Business Accounting and National Accounting. Handbook of National Accounting, Studies in methods, Series F No. 76. New York: United Nations.

United Nations (UN), European Commission (EC), International Monetary Fund (IMF), Organization for Economic Cooperation and Development (OECD), and the World Bank (WB) (2009), System of National Accounts 2008 (SNA 2008), Brussels/Luxembourg, New York, Paris, Washington D.C.

Van der Hoek, M. P. (2005). From cash to accrual budgeting and accounting in the public sector: The Dutch experience. Public Budgeting \& Finance, 25(1), 32-45.

Vanoli, A. (2005). A History of National Accounting. Fairfax, VA: IOS Press.

Verrinder, J. (2008). What are national accounts?, SIGMA 03/08 Eurostat publication office, pp. 5-7. 
Table 1: Main academic journals considered for search

\begin{tabular}{|c|}
\hline Name \\
\hline Public Money \& Management \\
\hline Financial Accountability and Management \\
\hline Abacus \\
\hline International Journal of Public Administration \\
\hline International Review of Administrative Sciences \\
\hline Accounting, Economics, and Law \\
\hline Critical Perspectives on Accounting \\
\hline European Accounting Review \\
\hline Public Budgeting \& Finance \\
\hline Research in Governmental and Nonprofit Accounting \\
\hline Accounting Forum \\
\hline Accounting in Europe \\
\hline Accounting Perspectives \\
\hline Accounting, Auditing \& Accountability Journal \\
\hline Canadian Journal of Administrative Sciences \\
\hline Innovar - Journal of Administrative and Social Sciences \\
\hline International Journal of Public Sector Management \\
\hline Journal of Business Finance and Accounting \\
\hline Journal of Comparative Policy Analysis: Research and Practice \\
\hline Notas Económicas \\
\hline OECD Journal on Budgeting \\
\hline RC-SAR - Revista de Contabilidad (Spanish Accounting Review) \\
\hline Review of Income and Wealth \\
\hline Statistika - Statistics and Economy Journal \\
\hline Transylvanian Review of Administrative Sciences \\
\hline
\end{tabular}

Abstracting/Indexing Number of papers

ABS/JCR/Scopus 10

ABS/Scopus 9

ABS/JCR/Scopus 3

ABS/Scopus 3

ABS/JCR/Scopus 3

--- 2

ABS/JCR/Scopus 2

ABS/JCR/Scopus 2

Scopus 2

2

ABS/Scopus 1

Scopus 1

Scopus 1

ABS/JCR/Scopus 1

ABS/JCR/Scopus 1

Scopus 1

ABS/Scopus 1

ABS/JCR/Scopus 1

JCR/Scopus 1

$\begin{array}{cl}--- & 1 \\ --- & 1 \\ \text { Scopus } & 1\end{array}$

ABS/JCR/Scopus 1

Scopus 1

Scopus 1

TOTAL 53

Table 2: Main non-academic papers/studies included in the analysis

\begin{tabular}{|c|c|}
\hline Preparer & Number \\
\hline EU/EC/Eurostat & 13 \\
\hline Standard setter: IFAC/IPSASB & 7 \\
\hline IMF & 7 \\
\hline National Statistics Institutions & 7 \\
\hline Standard setter: AASB & 5 \\
\hline Audit Firms & 4 \\
\hline United Nations & 3 \\
\hline Professional Associations & 3 \\
\hline Fédération des Experts Comptables Européennes & 1 \\
\hline European Central Bank & 1 \\
\hline National authorities & 1 \\
\hline Individual reports & 1 \\
\hline & 53 \\
\hline
\end{tabular}

Table 3: GA versus NA - main elements of the conceptual frameworks 


\begin{tabular}{|c|c|c|}
\hline Issue & $\overline{G A}$ & $N A$ \\
\hline SCOPE & Micro & Macro \\
\hline $\begin{array}{l}\text { REPORTING } \\
\text { BOUNDARY }\end{array}$ & $\begin{array}{l}\text { Reporting entity ranges from an } \\
\text { individual entity to the public } \\
\text { sector as a whole }\end{array}$ & $\begin{array}{c}\text { Institutional Unit / Institutional } \\
\text { sectors } \\
\text { GGS / public sector }\end{array}$ \\
\hline USERS & $\begin{array}{l}\text { Governments, international } \\
\text { organisations, taxpayers, } \\
\text { members of the legislature, } \\
\text { creditors, suppliers, media, } \\
\text { employees and the general public }\end{array}$ & $\begin{array}{c}\text { European Community } \\
\text { institutions, governments, } \\
\text { analysts and decision-makers of } \\
\text { fiscal policies and other social } \\
\text { and economic agents }\end{array}$ \\
\hline USERS' NEEDS & $\begin{array}{l}\text { Information about the financial } \\
\text { position, performance and cash } \\
\text { flows of an entity, as well as of } \\
\text { compliance with the approved } \\
\text { budget, useful for decision } \\
\text { making and evaluating about the } \\
\text { allocation of resources }\end{array}$ & $\begin{array}{l}\text { Aggregated data for economic } \\
\text { analysis, decision making and } \\
\text { policy making }\end{array}$ \\
\hline GOALS & $\begin{array}{l}\text { Management Analysis } \\
\text { Financial and budgetary } \\
\text { reporting }\end{array}$ & $\begin{array}{c}\text { Economic analysis } \\
\text { Fiscal policies-related decision } \\
\text { making }\end{array}$ \\
\hline OBJECTIVES & $\begin{array}{l}\text { Accountability } \\
\text { Decision making }\end{array}$ & $\begin{array}{l}\text { Analysis and evaluation } \\
\text { Providing information for } \\
\text { preparing, implementing and } \\
\text { monitoring the economic } \\
\text { policies of the European } \\
\text { Monetary Union }\end{array}$ \\
\hline RECOGNITION & $\begin{array}{c}\text { Budgetary accounting - cash } \\
\text { basis, modified cash basis or } \\
\text { accrual basis (with prevalence of } \\
\text { the former) } \\
\text { Financial accounting - cash } \\
\text { basis, modified accrual or full } \\
\text { accrual basis (with prevalence of } \\
\text { the latter) }\end{array}$ & $\begin{array}{c}\text { Full accrual basis for all } \\
\text { transactions (monetary and non- } \\
\text { monetary), except for taxes and } \\
\text { social contributions }\end{array}$ \\
\hline $\begin{array}{c}\text { INCOME/BUDGET } \\
\text { BALANCE } \\
\text { PERSPECTIVE }\end{array}$ & Comprehensive & $\begin{array}{l}\text { Other economic flows are } \\
\text { separated from revenue and } \\
\text { expenses }\end{array}$ \\
\hline MEASUREMENT & $\begin{array}{l}\text { Historical cost - purchase price } \\
\text { or production cost } \\
\text { Market prices exceptionally } \\
\text { admitted } \\
\end{array}$ & Market prices as main reference \\
\hline
\end{tabular}

Source: adapted from Jesus and Jorge (2010) and Dabbicco (2016) 
Table 4: GA versus NA: main divergences for analysis

\begin{tabular}{|l|l|}
\hline \hline \multicolumn{1}{|c|}{ Categories } & \multicolumn{1}{c|}{ Issues } \\
\hline $\begin{array}{l}\text { The scope of the reporting entity } \\
\text { and the scope of the government } \\
\text { sector reporting }\end{array}$ & $\begin{array}{l}\text { - The boundaries of the reporting entities according to each } \\
\text { reporting model } \\
\text { - Reporting components of the public sector, namely of the GGS } \\
\text { - Reporting for controlled entities }\end{array}$ \\
\hline $\begin{array}{l}\text { Recognition of assets, except } \\
\text { financial instruments }\end{array}$ & $\begin{array}{l}\text { - Definition of assets, liabilities, revenues, expenses and equity } \\
\text { - Specific issues, such as costs associated with research and } \\
\text { development, other intangible assets, extractive industries and } \\
\text { defence weapons } \\
\text { - Tax credits, tax gap and moment of recognising tax revenues } \\
\text { - Public-private partnerships }\end{array}$ \\
\hline $\begin{array}{l}\text { Measurement of assets, liabilities } \\
\text { and net assets (equity) }\end{array}$ & $\begin{array}{l}\text { - Several different criteria for measurement of each item, such as } \\
\text { impairment of non-financial assets, transaction costs, low } \\
\text { interests and interest free loans, inventories, investments in } \\
\text { associates and biological assets }\end{array}$ \\
\hline \hline
\end{tabular}

Source: Adapted from IPSASB (2005)

Table 5: Deficit-related adjustment categories and conceptual differences between GA and NA (according to the Excessive Deficit Procedure Tables 2)

\begin{tabular}{|c|c|}
\hline Adjustment categories & Conceptual differences \\
\hline Financial transactions included in the 'working balance' & \\
\hline Non-financial transactions not included in the 'working balance' & Classification of transactions \\
\hline $\begin{array}{l}\text { Accounting basis adjustments } \\
\text { - Differences between interest paid and interest accrued } \\
\text { - Other accounts receivable } \\
\text { - Other accounts payable }\end{array}$ & Recognition criteria differences \\
\hline $\begin{array}{l}\text { Balance (net borrowing or net lending) of other Central } \\
\text { Government entities } \\
\text { - 'Working balance' }(+/-) \text { of entities not part of Central } \\
\text { Government } \\
\text { - Net borrowing }(+) \text { or lending }(-) \text { of other Central } \\
\text { Government bodies }\end{array}$ & $\begin{array}{l}\text { Definition and scope of reporting } \\
\text { entity under GA and NA } \\
\text { Preparation and disclosure of } \\
\text { consolidated financial statements }\end{array}$ \\
\hline Other adjustments & $\begin{array}{l}\text { Relationship between government and } \\
\text { government business enterprises and } \\
\text { other reclassifications of specific } \\
\text { transactions }\end{array}$ \\
\hline
\end{tabular}

Source: adapted from Jesus and Jorge (2010) and Dasí et al. (2013) 
Table 6: Timeline in historical developments of GA and NA (1996-2018)

\begin{tabular}{|c|c|c|}
\hline Professional accounting and statistics reports & Years & Main topics in academic papers \\
\hline $\begin{array}{l}\text { In } 1995 \text {, SNA93 was adopted to the EU context - } \\
\text { ESA95 was approved and started to be } \\
\text { implemented. } \\
\text { Several national and European statistical bodies, } \\
\text { directly or using commissioned reports, debated } \\
\text { this new harmonised system for NA within the } \\
\text { EU. }\end{array}$ & & $\begin{array}{l}1996 \text { came to be a landmark, setting the } \\
\text { moment from which some academics } \\
\text { started to analyse the relationship between } \\
\text { GA and NA in the EU context, addressing } \\
\text { main conceptual differences and pointed for } \\
\text { the first time the need of a convergence }\end{array}$ \\
\hline $\begin{array}{l}\text { From middle } 1990 \text { s, international harmonisation } \\
\text { issues in GA and reporting started to be } \\
\text { considered. The first set of IPSAS derived from } \\
\text { IFRS started to be developed by the IFAC-PSC in } \\
\text { 1996. The convergence of IPSAS with IFRS } \\
\text { should be continuously assured, as much as } \\
\text { possible. } \\
\text { However, some European bodies, such as } \\
\text { Accountancy Europe and the EU, started to } \\
\text { identify inconsistencies between business } \\
\text { accounting principles and the National Statistics } \\
\text { principles (economics), even if ESA was based } \\
\text { on an accruals regime. }\end{array}$ & $\begin{array}{l}1996 \\
\text { to } \\
1999\end{array}$ & $\begin{array}{l}\text { between the two reporting systems. This } \\
\text { followed the approval of ESA95 and the } \\
\text { signature of the Maastricht Treaty in 1992, } \\
\text { establishing convergence criteria for MS } \\
\text { based on NA figures. An issue of the } \\
\text { journal Research in Governmental and Non- } \\
\text { Profit Accounting was dedicated to the } \\
\text { matter. } \\
\text { On the institutionalisation and } \\
\text { professionalization of GA and NA, a few } \\
\text { authors, in and out of the EU context, } \\
\text { discussed the role of the accounting versus } \\
\text { the economist profession, namely } \\
\text { discussing the role of both in the GA } \\
\text { reforms towards accruals, in the relationship } \\
\text { GA-NA and in the complementary } \\
\text { background of both fields ideally required } \\
\text { for a public sector administrator. }\end{array}$ \\
\hline $\begin{array}{l}\text { International and European bodies, such as the } \\
\text { AASB, the EC, the ECB, the IMF and the UN } \\
\text { debated and engaged in the development of } \\
\text { reports about the relationship between business } \\
\text { accounting and GAAP and the NA and statistics. } \\
\text { Eurostat Accounting \& Statistics Task Force } \\
\text { announced plans for major changes in EU } \\
\text { accounting, leading to legal requirements to MS } \\
\text { arising from the } 4^{\text {th }} \text { Directive on company } \\
\text { accounts and the } 7^{\text {th }} \text { Directive on consolidated } \\
\text { business accounts. There was attention on } \\
\text { conformity with the IAS. }\end{array}$ & \multirow{5}{*}{$\begin{array}{l}2000 \\
\text { to } \\
2004\end{array}$} & \multirow{5}{*}{$\begin{array}{l}\text { GA versus NA was the theme of a special } \\
\text { issue of Financial Accountability \& } \\
\text { Management in } 2000 \text {. The convergence } \\
\text { between the two systems was again the } \\
\text { main issue, with authors discussing the role } \\
\text { of budgeting and auditing in the process. } \\
\text { Country cases were considered, e.g. France } \\
\text { and the Netherlands. } \\
\text { The impact of the accrual basis and IPSAS } \\
\text { in the GA objectives was particularly } \\
\text { discussed. } \\
\text { Other academic studies analysed the GA } \\
\text { reforms process towards accruals and } \\
\text { international harmonisation, focusing on the } \\
\text { hindering factors and on the main actors in } \\
\text { the process. }\end{array}$} \\
\hline $\begin{array}{l}\text { In 2000, the UK adopts accrual-based statements } \\
\text { for Central Government (Local Government was } \\
\text { already using IFRS years before). GA Rules were } \\
\text { enacted in } 2000 \text {, leading to the intensification of } \\
\text { contacts with the Office for National Statistics } \\
\text { (ONS) to draw sources (coordination had already } \\
\text { started in the } 1990 \text { s). }\end{array}$ & & \\
\hline $\begin{array}{l}\text { In } 2002, \text { the EU Council adopted The Regulation } \\
\text { on the application of international accounting } \\
\text { standards for business accounting. }\end{array}$ & & \\
\hline $\begin{array}{l}\text { In } 2002, \text { Australia starts the } G A A P-G F S \\
\text { Harmonisation-Project, which was finalised in } \\
2013 .\end{array}$ & & \\
\hline $\begin{array}{l}\text { In 2002, work started towards the revision of } \\
\text { SNA93. Following Maastricht Treaty, it was } \\
\text { recognised that the SNA (and the ESA) needed to } \\
\text { contain further details and up-to-date } \\
\text { recommendations regarding the delineation of the } \\
\text { GGS and a harmonised treatment of specific }\end{array}$ & & \\
\hline
\end{tabular}




\begin{tabular}{|c|c|c|}
\hline Professional accounting and statistics reports & Years & Main topics in academic papers \\
\hline $\begin{array}{l}\text { transactions of the GGS, such as capital } \\
\text { injections, securitisation, etc. A special chapter } \\
\text { on general government would be included in the } \\
\text { SNA. The coordination of these } \\
\text { recommendations with the accounting principles } \\
\text { of other international standards (such as, the IMF } \\
\text { GFS and the IPSAS of the IFAC-PSC), } \\
\text { intensified. } \\
\text { In the EU context, the ESA95 review began. }\end{array}$ & & \\
\hline $\begin{array}{l}\text { In October 2003, IFAC and other international } \\
\text { bodies, such as the IMF, created a task force for } \\
\text { harmonisation in public sector accounting } \\
\text { (TFHPSA) aiming at promoting the convergence } \\
\text { between GAAP, GA standards and GFS and the } \\
\text { convergence between GFSM2001, SNA93 and } \\
\text { ESA95 (the statistical systems). An initial report } \\
\text { on the "Matrix" was published in } 2004 \text {. } \\
\text { In addition, IPSASB started issuing standards } \\
\text { addressing matters particular to public sector. }\end{array}$ & & \\
\hline $\begin{array}{l}\text { From } 2004 \text {, EU authorities acknowledged an } \\
\text { overall need to reinforce the credibility and } \\
\text { quality of the statistics, and started a European } \\
\text { Governance Strategy for Fiscal Statistics. }\end{array}$ & & \\
\hline $\begin{array}{l}\text { In 2005, IFAC/IPSASB issued an important } \\
\text { Research Report on the analysis of differences } \\
\text { and recommendations for convergence between } \\
\text { the IPSAS and Statistical Bases of Financial } \\
\text { Reporting. } \\
\text { In articulation with this, a final report of the } \\
\text { TFHPSA was published in } 2006 \text {. }\end{array}$ & \multirow{4}{*}{$\begin{array}{c}2005 \\
\text { to } \\
2009\end{array}$} & \multirow{4}{*}{$\begin{array}{l}\text { Regarding the professionals' topic, some } \\
\text { authors referred to the role of professional } \\
\text { consultants in the GA reforms in several } \\
\text { countries, such as Australia, Canada; others } \\
\text { took an international outlook on the same } \\
\text { subject. } \\
\text { On the NA side, academics continued to } \\
\text { highlight their purpose, resorting to } \\
\text { historical approaches. Several books were } \\
\text { produced, some under the auspices of } \\
\text { international bodies, such as OECD. Some } \\
\text { authors additionally addressed the (mis)use } \\
\text { of GFS. Other authors elaborated on fiscal } \\
\text { policy theories. } \\
\text { On the GA side, while some authors } \\
\text { explained and promoted IPSAS adoption, } \\
\text { even by publishing books, others started to } \\
\text { analyse IPSAS adoption in a more critical } \\
\text { way, e.g. linking the willingness of } \\
\text { governments to adopt them with the legal } \\
\text { and administrative traditions of the various } \\
\text { jurisdictions. } \\
\text { In the particular setting of the UK, the } \\
\text { debate was about the problems concerning } \\
\text { the Whole-of-Government accrual-based } \\
\text { financial reporting, considering the } \\
\text { developments meanwhile happening in the } \\
\text { project in practice. }\end{array}$} \\
\hline $\begin{array}{l}\text { Following ten years of IPSAS, in 2006, the } \\
\text { IPSASB issued two particular standards } \\
\text { somehow regarding the relationship between GA } \\
\text { and NA: IPSAS } 22 \text { - Disclosure of financial } \\
\text { information about the general government sector } \\
\text { and IPSAS } 24 \text { - Presentation of Budget } \\
\text { Information in Financial Statements. } \\
\text { On the other hand, at the end of } 2007 \text {, the basis } \\
\text { for changes in the NA were settled and the new } \\
\text { SNA } 2008 \text { was issued. Some individual reports } \\
\text { discussed the uses of NA data. }\end{array}$ & & \\
\hline $\begin{array}{l}\text { Coming in force from } 2009 \text {, SNA } 2008 \text { explicitly } \\
\text { mentions the IPSASB, acknowledging } \\
\text { commercial accounting as a conceptual point for } \\
\text { the NA; commercial accounting treatment was } \\
\text { examined to see whether it would provide any } \\
\text { help in NA. }\end{array}$ & & \\
\hline $\begin{array}{l}\text { During } 2008 \text { and } 2009 \text {, whereas in international } \\
\text { bodies, such as the IMF, the GA change to } \\
\text { accruals continued to be discussed, in the EU } \\
\text { context, the financial crisis led to concerns from } \\
\text { the EU authorities regarding the application of } \\
\text { the EDP Protocol. Regulation } 479 / 2009 \text { replaced } \\
\text { the previous one, to provide powers for Eurostat } \\
\text { to undertake 'upstream' controls, including } \\
\text { methodological visits. } \\
\text { By this time, the Australian standard-setters } \\
\text { started to address the relationship between Whole }\end{array}$ & & \\
\hline
\end{tabular}




\begin{tabular}{|c|c|c|}
\hline Professional accounting and statistics reports & Years & Main topics in academic papers \\
\hline $\begin{array}{l}\text { of Government and General Government Sector } \\
\text { Financial Reporting. }\end{array}$ & & \\
\hline $\begin{array}{l}\text { During this period, the IPSASB Project on } \\
\text { Alignment of IPSASs and Public Sector Statistical } \\
\text { Reporting Guidance continued. The IPSASB } \\
\text { Chair and the UK member became } \\
\text { members/observers of the GFS Advisory } \\
\text { Committee. In this process, in 2012, the IPSASB } \\
\text { developed first a "Consultation Paper" and then a } \\
\text { final project, on GFS/IPSAS alignment. }\end{array}$ & \multirow{6}{*}{$\begin{array}{l}2010 \\
\text { to } \\
2013\end{array}$} & \multirow{6}{*}{$\begin{array}{l}\text { This period seems to have been fruitful in } \\
\text { academic publications, with many } \\
\text { addressing the GA accounting reforms and } \\
\text { IPSAS, while others, though less, addressed } \\
\text { the GA-NA relationship. } \\
\text { In the first group, some explained how } \\
\text { IPSAS came about and continued enhancing } \\
\text { their advantages namely for improvements } \\
\text { in financial reporting transparency. Other } \\
\text { studies already explored experiences with } \\
\text { IPSAS adoption (e.g. in the EC). } \\
\text { The Australian GA reform saga is closed, } \\
\text { with authors explaining why Governments } \\
\text { should prefer NA over GA for their } \\
\text { reporting. } \\
\text { In the second group, in the European } \\
\text { setting, authors start discussing the } \\
\text { adjustments to be made when translating } \\
\text { data from GA into NA, calling attention to } \\
\text { the material implications these may have on } \\
\text { the reliability of the data finally reported; } \\
\text { with some suggesting that further } \\
\text { convergence should probably be considered. } \\
\text { Other authors highlighted the prominent } \\
\text { role of budgeting in this process. In the UK, } \\
\text { questions started raising concerns about the } \\
\text { role of Whole-of-Government accounts for } \\
\text { the EU fiscal surveillance process. } \\
\text { Other branches of literature highlighted the } \\
\text { normative powers of accounting } \\
\text { professionals in the reforms; the Australian } \\
\text { case seemed yet again to be emphasised. } \\
\text { The close link between the international } \\
\text { standard-setters for business and public } \\
\text { sector accounting (IASB and IPSASB) is } \\
\text { highlighted. }\end{array}$} \\
\hline $\begin{array}{l}\text { In the EU, the concerns regarding the robust } \\
\text { quality of European statistics continued. } \\
\text { Subsequently, between } 2011 \text { and } 2013 \text {, several } \\
\text { EU legislations addressed the matter - the «Six } \\
\text { Pack» on European fiscal and macroeconomic } \\
\text { policy and monitoring framework entered in } \\
\text { forced. The subsequent "Two pack" created the } \\
\text { possibility for the Commission to propose fines } \\
\text { for Euro Area MS which manipulate statistical } \\
\text { data. } \\
\text { In the same line, the IMF issued a report on } \\
\text { Fiscal Transparency, Accountability, and Risk. } \\
\text { In many professional reports, the debate shifted } \\
\text { focus from the public deficit to the public debt in } \\
\text { MS. This debate seems to have been a } \\
\text { consequence of the sovereign debts crises. }\end{array}$ & & \\
\hline $\begin{array}{l}\text { In the context of the «Six Pack», the EU } \\
\text { addressed accounting issues and required the } \\
\text { Commission to assess the suitability of IPSAS for } \\
\text { EU countries by the end of } 2012 \text {. } \\
\text { A first report was produced by EY, comparing } \\
\text { the current state of public sector accounting } \\
\text { across the MS. }\end{array}$ & & \\
\hline $\begin{array}{l}\text { Technical issues concerned Whole-of- } \\
\text { Government accounts were addressed and } \\
\text { published by the ONS UK. }\end{array}$ & & \\
\hline $\begin{array}{l}\text { In } 2013 \text {, the EC issued a final report of the } \\
\text { possibility of implementing harmonised GA } \\
\text { standards in MS, addressing the suitability of } \\
\text { IPSAS. The report acknowledged that, despite an } \\
\text { indisputable international reference, IPSAS as } \\
\text { they stood, were not suitable for the EU context, } \\
\text { so EPSAS would be needed. } \\
\text { The European contribution to the international } \\
\text { accounting standard-setting process was } \\
\text { reinforced by a report in October, raising similar } \\
\text { questions concerning the IFRS. } \\
\text { The EPSAS project started in 2013. }\end{array}$ & & \\
\hline $\begin{array}{l}\text { Standard-setters internationally, e.g. in Australia } \\
\text { and in Sweden, continued debating the } \\
\text { convergence between accounting, GAAP and } \\
\text { GFS. }\end{array}$ & & \\
\hline $\begin{array}{l}\text { In the GFS/IPSAS alignment, a policy paper was } \\
\text { issued by the IPSASB in 2014, explaining how } \\
\text { IPSAS should be developed to assure } \\
\text { convergence with GFS. }\end{array}$ & $\begin{array}{c}2014 \\
\text { to } \\
2015\end{array}$ & $\begin{array}{l}\text { On the NA side, due to ESA2010, some } \\
\text { authors updated their books. } \\
\text { In the GA-NA relationship, there was a } \\
\text { seminal chapter by Jones (2014), on the }\end{array}$ \\
\hline
\end{tabular}




\begin{tabular}{|c|c|c|}
\hline Professional accounting and statistics reports & ears & \multirow{5}{*}{\begin{tabular}{|l}
\multicolumn{1}{|c|}{ Main topics in academic papers } \\
history, development and overlaps between \\
NA and GA (including budgeting). Some \\
other papers stressed the need for EPSAS to \\
address budgeting issues. \\
As to empirical research, despite the new \\
ESA2010 in practice from 2014, academic \\
research continued using data from ESA95. \\
A large group of papers addressed the \\
deficit-related adjustments when translating \\
data from GA into NA, their diversity, \\
materiality and determinant factors. The \\
main issues related to calling attention to: \\
possible creative use of accounting, \\
questioning the reliability of the data finally \\
reported in NA, and questioning the need \\
for GA-NA convergence, especially \\
concerning accrual-based budgetary \\
reporting as part of GA and providing the \\
main inputs to NA. \\
Some papers already addressed the role of \\
IPSAS/EPSAS in the institutional drift \\
between GA and NA. \\
The Finish case was discussed as a \\
resistance case to IPSAS-type of accruals. \\
On the professionals' topic, the link \\
between the professionalization of public \\
sector accountants and the adoption of \\
accruals for GA was underlined.
\end{tabular}} \\
\hline $\begin{array}{l}\text { In 2014, the EU started implementing the new } \\
\text { ESA2010, which contained a new chapter on the } \\
\text { accounts of GGS. } \\
\text { The IMF updated their GMFS Manual. }\end{array}$ & & \\
\hline $\begin{array}{l}\text { PwC developed two studies commissioned by the } \\
\text { EU regarding the adoption and IPSAS and their } \\
\text { impact on MS, including cost-related issues. }\end{array}$ & & \\
\hline $\begin{array}{l}\text { The ACCA in UK discusses the use of } \\
\text { Consolidated Government Accounts. }\end{array}$ & & \\
\hline $\begin{array}{l}\text { From } 2014 \text { onwards, the "GFS Tracking Table" } \\
\text { started being published, updated and made } \\
\text { available for each IPSASB meeting. Such a } \\
\text { tracking table identifies differences and compares } \\
\text { the requirements for IPSAS and GFS. }\end{array}$ & & \\
\hline $\begin{array}{l}\text { In 2016, a study by PwC, commissioned by the } \\
\text { ICAEW, went back to highlighting the } \\
\text { importance of having good and reliable } \\
\text { information for better and more sound } \\
\text { government finances. Integrated financial } \\
\text { information was underlined as crucial to fill the } \\
\text { measurement gap. } \\
\text { The IMF continues highlighting the need to } \\
\text { further alignment between GA (IPSAS) and NA } \\
\text { (GFS). } \\
\text { The imperative character of this alignment is also } \\
\text { clear in the IPSASB' proposed strategy and work } \\
\text { plan } 2019-2023 \text {, released in January } 2018 \text {. } \\
\text { The AASB just published a report on key issues } \\
\text { for public sector financial reporting, namely } \\
\text { addressing GFS Reporting. } \\
\text { The EPSAS project from 2016 to date, has } \\
\text { focused on harmonising public sector accounting } \\
\text { technical issues, publishing some papers on } \\
\text { selected public sector specific topics, e.g. first } \\
\text { time adoption of accrual accounting and military } \\
\text { assets. } \\
\text { In this period, the discussion focuses on balance } \\
\text { sheets and accounting for government debt; for } \\
\text { example, ICAEW just issued a report providing } \\
\text { insights about The Debt of Nations. }\end{array}$ & $\begin{array}{c}2016 \\
\text { to } \\
2018\end{array}$ & $\begin{array}{l}\text { The questions concerning convergence } \\
\text { between GA-NA continued being discussed. } \\
\text { Several papers continued highlighting the } \\
\text { diversity and materiality of the adjustments, } \\
\text { finally showing that IPSAS or IPSAS-based } \\
\text { GA system shall not reduce them. Studies } \\
\text { using the ESA2010 framework showed that } \\
\text { IPSAS sometimes even increased the GA- } \\
\text { NA divergence. } \\
\text { Other group of studies addressed more } \\
\text { technical issues, apparently in response to } \\
\text { the earlier periods professional reports - } \\
\text { e.g. debt and other liabilities reporting and } \\
\text { measurement criteria and how these can } \\
\text { lead to misinterpretation. } \\
\text { Finally, a third group addressed the } \\
\text { relevance of using GA and/or GFS for fiscal } \\
\text { surveillance. } \\
\text { About the professionals, one study analysed } \\
\text { the roles of accountants within technical } \\
\text { units as "brokers", who provide information } \\
\text { that meets politicians' needs. }\end{array}$ \\
\hline
\end{tabular}

